\title{
多層膜冷中性子干渉計の最近の展開
}

\author{
北口 雅暁 \\ (京都大学大学院理学研究科)
}

\section{Recent progress of cold-neutron interferometer using multilayer mirrors}

Masaaki Kitaguchi

Department of Physics, Kyoto University

\section{0}

\begin{abstract}
A novel type of cold-neutron interferometer has been developed. It contains a pair of new devices named 'beam splitting etalons (BSEs),' which enable us to align four independent multilayer mirrors in the interferometer within required precision. In this paper the recent progress of the interferometer using etalons will be reported. The future prospect of some applications for fundamental physics will be also discussed.

Keywords: cold-neutron interferometer, etalon
\end{abstract}

中性子干渉実験は基礎物理学の強力な研究手法 です．干渉計の検出器としての高感度化には長波 長中性子への適用と装置の大型化が重要ですが, 最近多層膜ミラーを用いての取り組みに新しい展 開がありました。この稿ではその現状と今後の可 能性について報告します。

\section{1.はじめに}

シリコン完全単結晶による熱中性子干渉計の成 功[1]以来, 中性子干渉実験は基礎物理・物性物理 においてめざましい成果を上げています. 中性子 波動関数に対する重力の効果の検出 (COW 実験) [2,3]やスピノルの $4 \pi$ 回転対称性の検証[4]など, 中 性子干涉実験は量子力学における様々な実験を実 際に可能にしてきました，干渉計は波動関数の位 相差を通じて相互作用を測定する超高感度検出器 であり，基礎物理実験でこれからも重要な役割を 演じてゆくでしょう．本稿で紹介する多層膜を用 いた冷中性子干渉計はパルス中性子にも適用でき，

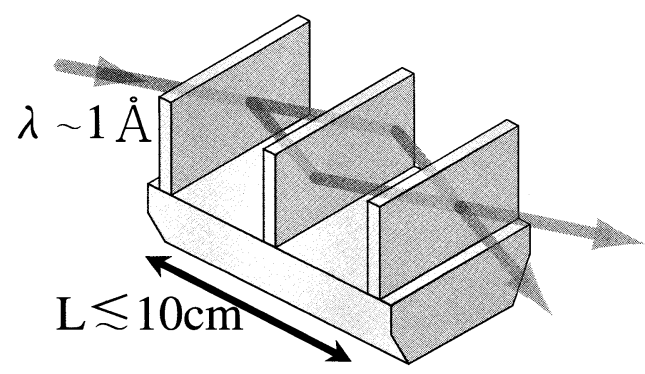

Fig. 1. Si perfect single crystal interferometer.
J-PARC の大強度中性子源を用いることでパルス 中性子の特性を生かした新しい実験も期待できま す $[5,6]$.

さて一般に干渉計は 2 つ分割された波の経路 でできていますが，2 つの経路上での相互作用の 違いで位相差が作られ，重ね合わされた結果その 位相差は計数变化となって観測されます。性子 は質量やスピン・磁気モーメントを持つ核子なの で中性子干渉計では重力・スピン相互作用・磁気 相互作用・核力によって位相差が生じます，中性 子干渉計が検出する位相差 $\Delta \phi$ は

$$
\Delta \phi=2 \pi \frac{m \lambda L}{h^{2}} \Delta E
$$

（ $m$ は中性子の質量は， $\lambda$ は波長， $h$ はプランク 定数, $L$ は相互作用する経路の長さ, $\Delta E$ は探索す る相互作用）と書け, 中性子の波長が長いほど, また相互作用する距離が長いほど，微小な相互作 用に対する感度が良くなります。つまりより高感 度の実験のためには, 干渉計の長波長中性子への 適用と装置の大型化が重要になります。これに対 し,シリコン完全単結晶を使った中性子干渉計

(Fig. 1) では経路の分割と重ね合わせに結晶格子 による回折を利用しているため, 適用可能な中性 子の波長は結晶の格子定数程度に制限されます。 相互作用する経路の長さも育成できる単結晶の大 きさに制限されてしまいます。ささらに動力学的回 折のために結晶内で経路が広がり干渉計の 2 経路 を正確に決定できず，測定精度を下げる要因にな っています。

これらの問題を解決する方法の一つが，中性子 


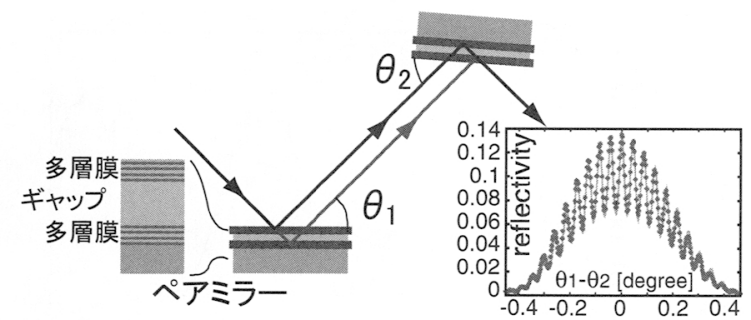

Fig. 2. Cold-neutron interferometer using multilayer mirrors.

多層膜ミラーを用いる干渉計です。

2. 多層膜ミラーと冷中性子干渉計

長波長中性子を扱う光学素子として多層膜ミラ 一があります。低エネルギーの中性子が物質に入 射する際には反射や屈折といった現象を示し, 物 質に対して有効ポテンシャルを考えることができ ます。ポテンシャルの異なる 2 種類の物質を交互 に積層した多層膜は入射中性子に対し 1 次元結晶 として振舞い，冷中性子を Bragg 反射するミラー として機能します。これが中性子多層膜ミラーで す。また多層膜の 2 つの物質の一方を磁性体にし て中性子のスピンによって選択的に反射し，偏極 装置や偏極分析装置として用いることができます。 これは磁気ミラーと呼ばれています。

多層膜ミラーを用いた冷中性子干渉計の可能性 はペアミラーと呼ばれる素子の使用によって示さ れました[7]. ペアミラーは真空蒸着によって 1 枚 のシリコンウエハの上に多層膜ミラー・中間層 · 多層膜ミラーと順に積層したもので，入射中性子 を2つの空間的経路に分割します（Fig. 2)。また この際 2 経路間にはミラー間の距離 $D$ に基づく光 路差 $2 D \sin \theta$ 年元られます（日はミラーへの入射 角). 2 つ目のペアミラーによる反射で 2 経路は再 び重ね合わされ，さらに光路差が補償されて位相 差 0 付近での明暸な干渉縞を観測する事ができま す. Fig. 2 は 2 つのペアミラーへの入射角の相対 角 $\left(\theta_{1}-\theta_{2}\right)$ に対する干渉縞を示しています。

その後, ペアミラーの表側のミラーを磁気ミラ 一にしたスピンスプリッタと呼ばれる素子を用い た中性子スピン干渉計[8]が開発されました。これ は空間的 2 経路を中性子のスピン状態によって分 割し, 高い反射率と高いコントラストの干渉縞を 得ることを可能にしました。多層膜ミラーを用い るこれらの干涉計は長波長中性子を扱う事ができ，

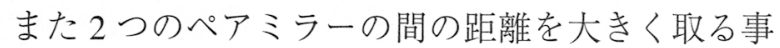
で相互作用する距離を拡大する事が可能です。し
かし蒸着によるミラー形成という技術的な理由か ら, ペアミラーやスピンスプリッタの中間層の厚 さは $1 \mu \mathrm{m}$ 程度にとどまっていました。このため 2 経路の空間的分離は小さく実際にはほとんど重な って扔り，これらの干渉計は応用に扔いて制限さ れていました. 2 経路の空間的分離を大きくでき れば，経路の一方にのみ装置を挿入するなど新し い実験が可能になります。また検出される相互作 用の大きさが経路の囲む面積に依存するようなも のでは, 経路の空間的分離が大きな干渉計でより 高感度な実験を行なうことができます。

3.ビームスプリッティングエタロンと Jamin 型干 渉計

経路間隔を大きくするために我々が用いたのが エタロンという素子です。エタロンは主にレーザ 一光学でFabry-Perot干渉計として用いられるもの で, 平面度の良い基板を平行度良く組み合わせた

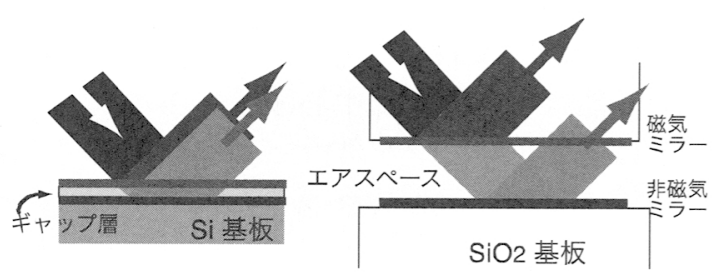

Fig. 3. Spin splitter and beam splitting etalon to enlarge the beam separation.

ものです。一般のレーザー用のエタロン基板は表 面粗さが中性子ミラーの基板としては十分ではあ りませんが, 現在では特に表面粗さの良好なもの， RMS が $3 \AA$ 似下程度のものを入手でき, 中性子ミ ラーの基板として用いる事ができます。エタロン の相対平面度は $\lambda_{\mathrm{He} \cdot \mathrm{Ne}} / 150$ と干渉計を構成するのに 十分です。エタロンの平行な 2 面に中性子多層膜 ミラーを形成し, 冷中性子を斜入射させると, 工 タロンはそのギャップを中間層とみなせるぺアミ ラー・スピンスプリッタとして機能します (Fig. 3). これを「ビームスプリッティングエタロン (BSE)」 と名付けました。ギャップの大きなビームスプリ ッティングエタロン 2 つを用いる事で経路間隔の 大きな干渉計を作成する事が可能になります。
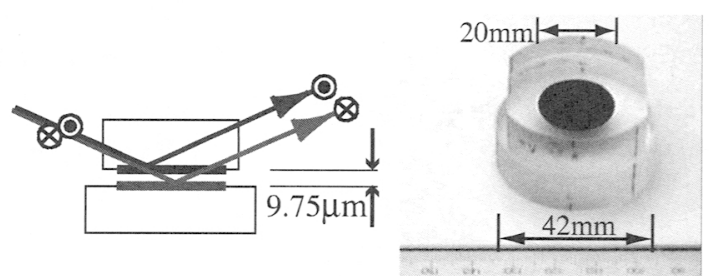

Fig. 4. Beam splitting etalon with the spacing of $9 \mu \mathrm{m}$ 

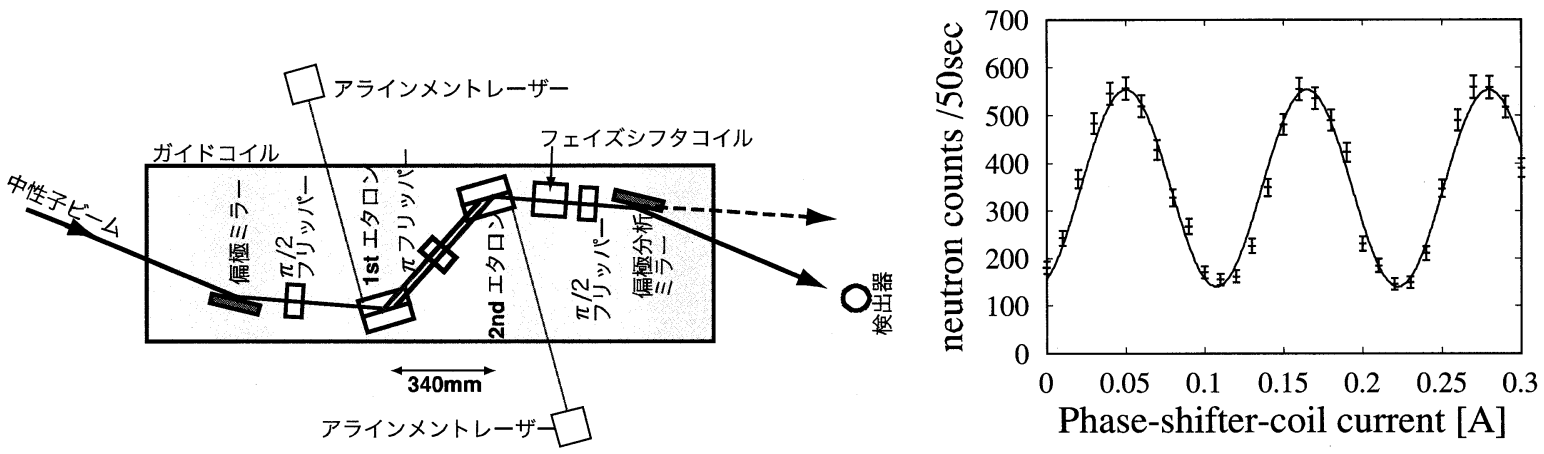

Fig. 5. Experimental setup of Jamin-type interferometer and interference fringes.

今回実証のために一方の面に磁気ミラー パー マロイ $45 / \mathrm{Ge}$ 多層膜 8 複層を, もう一方の面に非 磁気ミラー $\mathrm{Ni} / \mathrm{Ti}$ 多層膜 8 複層を蒸着したエ夕ロ

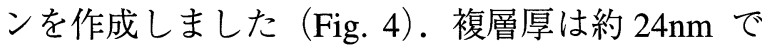
す.ギャップは約 $10 \mu \mathrm{m}$ で，これまでのスピンス プリッタの中間層の厚さの約 10 倍です.実験は日 本原子力研究所改 3 号炉冷中性子ビームライン C3-1-2`MINE2' で行ないました.中心波長 $8.8 \AA$ ， 波長分解能は半值全幅で中心波長の $2.7 \%$ す. 実 験配置は中性子スピン干渉計と基本的に同じです。 入射中性子ビームは偏極ミラーと $\pi / 2$ フリッパー によってガイド磁場とスピン平行な成分とスピン 反平行な成分との重和合わせ状態になり，エ夕ロ ンに入射されます。エタロンの磁気ミラーはスピ ン平行成分のみを反射し，透過したスピン反平行 成分は奥の非磁気ミラーによって反射されます. これによって入射中性子はスピンによって特徴づ けられた空間的 2 経路に分離されます。 パーによってスピンを反転し再びエタロンに入射 することで $2 つ の$ 経路は空間的に重ね合わされ， 最後に $\pi / 2$ フリッパーにより基底を取り直すこと で 2 つの成分の重ねあわせが得られます．2 経路 間の位相差は位相制御コイルによる磁場により制 御する事ができます（Fig. 5)。この配置は，幾何 光学の観点からは光学における最も古い干渉計で ある Jamin 干渉計と等価なものと言えます。我々 はこの干渉計でコントラスト $60 \%$ の干渉縞を観 測しました. 2 つのエタロンの相対角の変化に対 しての干渉縞の振る舞いから，この縞が空間的に 分離した 2 経路間の干渉であることを確かめてい ます[9].この縞の 1 周期は 2 経路間の $20 \mathrm{peV}$ の工 ネルギー差に相当し，この干渉計は $\mathrm{peV}$ を検出す る検出器であると言えます. 4 枚の独立に作成し た多層膜ミラーを組み合わせた冷中性子干渉計と しては世界初の成功です。

ビームスプリッティングエタロンを用いること で干渉光学系の経路を自在に操ることが可能にな ります。その一例として冷中性子ビームの横方向
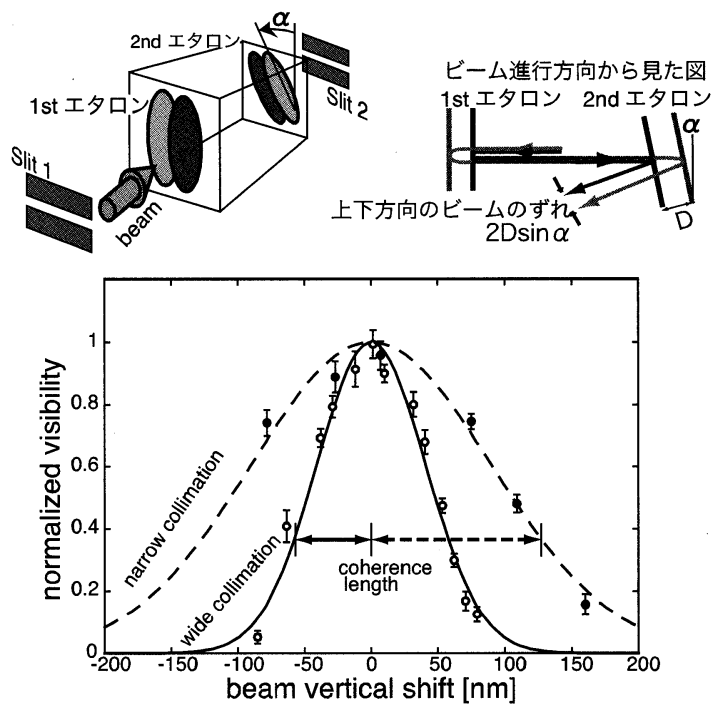

Fig. 6. Direct measurement of the transverse coherence length.

(Top) Tilting of the 2nd BSE makes vertical shift of the beam. (Bottom) Loss of contrast as a function of the vertical shift. Wide collimation: Two slits with the width of $40 \mathrm{~mm}$ and the distance between the slits of $4855 \mathrm{~mm}$ give the estimated value of the coherence length of $59 \mathrm{~nm}$. Measured value was $58 \pm 2 \mathrm{~nm}$. Narrow collimation: Two slits with the width of $10 \mathrm{~mm}$ and the distance of $2675 \mathrm{~mm}$ give the estimated value of $130 \mathrm{~nm}$. Measured value was $129 \pm 10 \mathrm{~nm}$.

可干涉長の直接測定を紹介しましょう[10]. 第 2

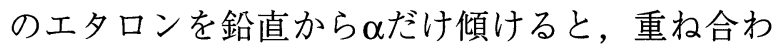

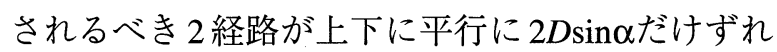
ます（Fig. 6)，傾きを調節することでずれの量を 自由に変えることができ, 図はその際の干渉縞の コントラストの変化，つまり可干渉性を示してい ます．ビームラインの上下方向の運動量分布の標 準偏差を $\sigma_{\mathrm{T}}$, ビームの分離を $L_{\mathrm{T}}$ とすると, 干渉縞 のコントラストは 


$$
\exp \left(-\frac{1}{2} \sigma_{\mathrm{T}}{ }^{2} L_{\mathrm{T}}{ }^{2}\right)
$$

にしたがって減衰し，コントラストが $1 / e$ になる 分離を可干渉長と定義します．実験ではビームラ インのコリメーションから見積もられる可干渉長 と測定值とがよく一致していることを確認しまし た。シリコン干渉計を用いたこれまでの干渉長の 測定では経路の分離に物質による屈折を利用して いたため分散なしに測定することが困難でした。 多層膜ミラーによる鏡面反射を用いたこの光学系 では分散なしに経路を制御することが可能です。

\section{4. 今後の可能性}

- 干渉計を使った基礎物理実験一

今回のビームスプリッティングエタロンのギャ ップは $10 \mu \mathrm{m}$ と小さく実際には 2 経路は未だ空間 的に重なっています. 既にギャップ $200 \mu \mathrm{m}$ のエ夕 ロンを作成し，その反射によって空間的に完全に 分離した 2 つ経路が得られる事を確認しています。 このエタロンによる Jamin 型干渉計は 2 経路が空 間的に分離し，一方の経路にのみ装置を挿入する こともできます。現在実際に干渉計を構成する準 備を進めています。

Jamin 型干渉計の成功は, エタロンを用いるこ とで多層膜ミラーを高精度に配置し, 冷中性子干 渉計を構成できる，ということを実験的に示して います。また干渉性の測定を通じて，干渉計の配 置に必要な精度をビームラインからあらかじめ見 積もれることを示しました。これらの知見を得て より大型の干渉計の開発をスタートさせています。

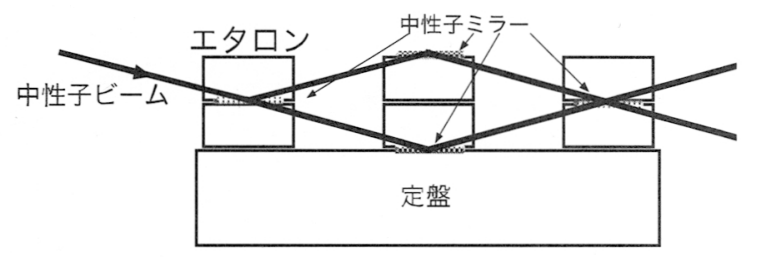

Fig. 7. Mach-Zehnder interferometer.

基板の両面が平行で厚さのそろった 6 枚のエ夕 ロン基板と, 平面度 $\lambda_{\mathrm{He-Ne}} / 20$ 程度の高精度定盤を Fig. 7 のように配置すれば，Mach-Zehnder 型と呼 ばれる冷中性子干渉計を構成することができます。 経路の分離を飛躍的に拡大させる Mach-Zehnder 型冷中性子干渉計の開発によってさらに様々な基 礎物理実験への応用が可能になるでしょう。現在 長さ約 $50 \mathrm{~cm}$ の定盤と厚さ $5 \mathrm{~mm}$ のエタロン基板を 用いた Mach-Zehnder 型干渉計を試作し，実験を始 めています. Mach-Zehnder 型干渉計の経路を調整 するための, より高精度な制御技術も研究されて います。

多層膜を用いた中性子干渉計は，基本的にパル ス中性子に対応できます。多層膜ミラーの各層の
厚さを徐々に変化させ幅広い波長の中性子を反射 する中性子スーパーミラーをエタロンに形成する だけで白色対応の干渉計になります。時間分析に よって相互作用の波長依存性を効率よく測定する ことができます。これは単結晶を用いた干渉計で は得られない特徴です. J-PARC の大強度中性子源 の建設と近年の多層膜作製技術の向上は, 多層膜 を用いた干渉実験を強力に後押しするでしょう。

大型の多層膜冷中性子干涉計による基礎物理実 験を2つ紹介します。

(1)Aharonov-Casher 効果

磁気モーメントを持つ粒子が電荷を取り囲む経 路を通る際に位相変化を受けるという Aharonov-Casher 効果は,ちょうどAharonov-Bohm 効果の磁場と電荷の関係を逆にしたものです[11]. 実験的には干渉計の 2 つの経路に静電ポテンシャ ルを印加することで実現され (Fig. 8), 中性子は 電荷を持たず磁気能率を持つので中性子干渉計は この実験に適しています。その位相変化は

$$
\phi_{\mathrm{AC}}= \pm \frac{4 \pi \mu \Lambda}{\hbar c}, \Lambda=2 L E / 4 \pi
$$

( $\mu$ は磁気モーメント， $\Lambda$ は線電荷密度, $L$ は相互 作用する距離, $E$ は電場） と書け，相互作用する 経路が大きいほど高感度で検出する事ができます。 シリコン単結晶を用いた熱中性子干渉計による過 去の実験では位相変化の量のずれが報告されてい ますが，実験精度が十分ではありません[12]，近 年原子干渉計を用いた高い精度の測定もなされて いますが，干渉計の 2 経路が空間的に分離できな いため経路が電荷を囲んでおらず幾何的性質が異 なるという指摘もあり, 経路の分離した中性子干 渉計での検証が必要です。

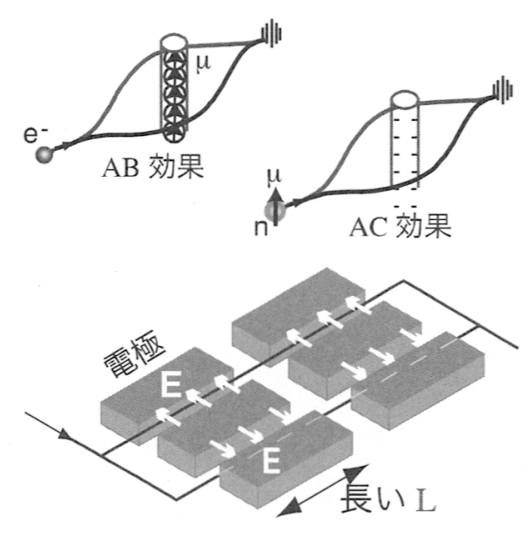

Fig. 8. Aharonov-Casher effect.

Jamin 型多層膜冷中性子干渉計はシリコン単結 晶による干渉計に比べ長い相互作用距離を取るこ とができます。前述のギャップ $200 \mu \mathrm{m}$ のビームス プリッティングエタロンを用いた干渉計に電極を 挿入し, シリコン単結晶の実験の約 10 倍の精度で 
測定する計画を現在進めています.

(2)中性子波動関数に対する重力の効果

重力ポテンシャルの異なる経路を中性子波が通 る際の位相差の検出 (COW 実験) では，感度は 波長と経路の囲む面積に比例します。

$$
\phi_{g}=-2 \pi m^{2} \frac{g}{h^{2}} \lambda A \sin \theta
$$

（ $\mathrm{g}$ は重力加速度， $\lambda$ は中性子波長， $A$ は経路が囲 む面積， $\theta$ は装置の傾き)。シリコン完全単結晶干 渉計での過去の実験と理論との間に位相変化の 0.8\%のずれがある，との報告があります[3]. この ずれに対しニュートン近似とは違う理論の提唱も あり，より高精度の測定が期待されています。経 路の空間的分離が大きい Mach-Zehnder 型多層膜 干渉計は面積を大きく取ることができます，多層 膜ミラーのブラッグ反射を使っている多層膜冷中 性子干渉計はシリコン干渉計に比べて動的回折の 補正が小さくて済み，議論が簡単になります。

\section{5.まとめ}

エタロンを用いることにより 4 枚の独立な基板 上の多層膜ミラーによって冷中性子干渉計を構成 することに成功し，様々な中性子干渉光学系を開 発する可能性を開きました。現在より大型の干涉 計の開発と基礎物理への応用を進めています。

\section{謝辞}

この研究は京都大学理学部の舟橋春彦氏, 名倉 照直氏, 竹谷薰氏, 京都大学原子炉実験所の日野 正裕氏, 理化学研究所の清水裕彦氏, 大竹淑恵氏 との共同研究です．京都大学工学部の丸山龍治氏 ほか多くの方の協力があります。科学研究費補助 金, 日本原子力研究所黎明研究, 松尾学術振興財 団の助成を受けています。また著者は理化学研究 所ジュニアリサーチアソシエイトとして研究に参 加する機会を得ました。実験では日本原子力研究 所, 東京大学物性研究所, 京都大学原子炉実験所 のお世話になっています。ここに感謝の意を表し ます。

\section{参考文献}

[1] H.Rauch, W.Treimer, U.Bonse, Phys. Lett. A47, 369 (1974).

[2] R.Collella, A.W.Overhauser, S.A.Werner, Phys. Rev. Lett.34, 1472 (1975).

[3] K.C.Littrell, B.E.Allman, S.A.Werner, Phys. Rev. A56, 1767 (1997).

[4] H.Rauch, A.Wilfing, W.Bauspiess, U.Bonse, Z. Phys, B29, 281 (1978).

[5] R.Maruyama, S.Tasaki, M.Hino, M.Takeda, T.Ebisawa, Y.Kawabata, Nucl. Inst. and Meth.A, in press.
[6] 舟橋春彦, 原子核研究, to be published.

[7] H.Funahashi, T.Ebisawa, T.Haseyama, M.Hino, A.Masaike, Y.Otake, T.Tabaru, S.Tasaki, Phys. Rev. A54, 649 (1996).

[8] T.Ebisawa, S.Tasaki, M.Hino, N.Achiwa, Y.Otake, H.Funahashi, D.Yamazaki, T.Akiyoshi, Phys. Rev. A57, 4720 (1998).

[9] M.Kitaguchi, H.Funahashi,' T.Nakura, M.Hino, H.M.Shimizu, Phys. Rev. A67, 033609 (2003).

[10] M.Kitaguchi, H.Funahashi, T.Nakura, K.Taketani, M.Hino, Y.Otake, H.M.Shimizu, J. Phys. Soc. Jpn. 72, 3079 (2003).

[11] Y.Aharonov, A.Casher, Phys. Rev. Lett. 53, 319 (1984).

[12] A.Cimmino, G.I.Opat, G.Klein, Phys. Rev. Lett. 63, 380 (1989). 